\title{
PASSENGER CARS BREAKING AFTER TYRE PUNCTURE BY TIRE DEFLATION DEVICE IN THE CASE OF STANDARD AND RUN ON FLAT TYRE TYPE
}

\author{
PIOTR STRYJEK'', GRZEGORZ MOTRYCZ², JERZY GRZESIAK ${ }^{3}$ \\ Military Institute of Armoured and Automotive Technology \\ In cooperation with: AMZ KUTNO www.amz.pl
}

\section{Summary}

Operation of stopping the driver that don't subordinate to the police order is very difficult and danger. Hazard can concern both the officer, halted person and third party persons. In the scope of tests there have been done series of controlled runs over the road spike strip with different speeds, beginning from typical town traffic sped, up to the speeds characteristic for driving on motorway. It has been tested not only the car behaviour during the moment of tire puncture, but also stability and driveability when driving with already failed tire. It has been done comparison of standard tyres and Run On Flat tyres, that enables driving without pressure. For both tyre types have been done tests of breaking effort and realized tour drives up to complete destroying the tyre shoulder. This test aimed to test usefulness the Run On Flat tyres for police vehicles. The job has been realized within a framework of research - developing project nr OR00000911, "Elaborating the technical requirements and range of necessary equipment for police vehicles, on the base of tests of standard demonstrations" carried out by Military Institute of Armoured and Automotive Technology in cooperation with Firm AMZ, Kutno.

Keywords: police vehicles, vehicle breaking with failed tyres, Run On Flat, stability and driveability.

\footnotetext{
' Okuniewska 1 Str., 1 05-070 Sulejówek, Poland, ph.: +48 2268110 44, e-mail: piotr@stryjek.eu, fax: +48 6811073 ${ }^{2}$ Okuniewska 1 Str., 1 05-070 Sulejówek, Poland, ph.: +48 2268110 44, e-mail: grzegorz.motrycz@witpis.eu, fax: +48 6811073

${ }^{3}$ Okuniewska 1 Str., 1 05-070 Sulejówek, Poland, ph.: +48 2268110 44, fax: +48 6-811-073
} 


\section{Introduction}

Operation of stopping the driver that don't subordinate to the police order is very difficult and danger. Hazard can concern both the officer, halted person and third party persons. It is connected not only with the moment of tire puncture in halted vehicle but also with continuing the driving after the tyre puncture. Vehicle without the air pressure in the tyres is very difficult in driving and it's stability is very restricted.

In the scope of tests there have been done series of controlled runs over the road spike strip with different speeds.

In the scope of tests there have been done series of controlled drive over the road spike strip with different speeds. It has been tested not only the car behaviour during the moment of tire puncture, but also stability and driveability when driving with already damaged tire. It have been tested not only the car behaviour during the moment of tire puncture but also the behaviour when driving with already damaged tire. There have been carried out the comparison of standard tires and Run On Flat (RSC) tyres that enable driving without air pressure.

The job has been realized within a framework of research - developing project $\mathrm{nr}$ OR00000911, "Elaborating the technical requirements and range of necessary equipment for police vehicles, on the base of tests of standard demonstrations" carried out by Military Institute of Armoured and Automotive Technology in cooperation with Firm AMZ, Kutno.

Police vehicles very often drive as privileged vehicles achieving high speeds in open road traffic. Therefore parameters connected with the vehicle stability and driveability should be very high. The vehicles should be either accommodated to overcome typical urban and land obstacles, which can encounter during pursuit on the hardened and gravel road. RSC tyres characterize strengthened sidewalls and ply design. This features cause that tyres of this type could be the optional equipment for police vehicles. Tyre of RSC type theoretically should be more resistive to mechanical damage, thus improving police vehicles mobility.

\section{Stopping vehicle by the use of road spike strip}

Assembly of the road spike strip consists of the series of thin sharp tipped tubes. When vehicle is driving over the spike strip, follows the penetration the tube into tyre and purposeful draw up the tube from the spike stripe (Fig. 1 and 2). It has a purpose to speed up the process of tire deflation. In the case when spike stripe had been assembled of uniform solid spikes, that additionally, after the vehicle drive remain in the stripe, the tyre puncture could be self sealed, and the effectiveness of the pressure drop in the tyre could be very law.

It has been tested the vehicle breaking distance for vehicles with good and punctured tyres. Tests have been done with good tires, one punctured tire and two punctured tyres of front axle. The tests have been carried out for speeds 60 and $80 \mathrm{kph}$. In this place it is to emphasize that exists some random number of tyres punctured during the drive thru. 


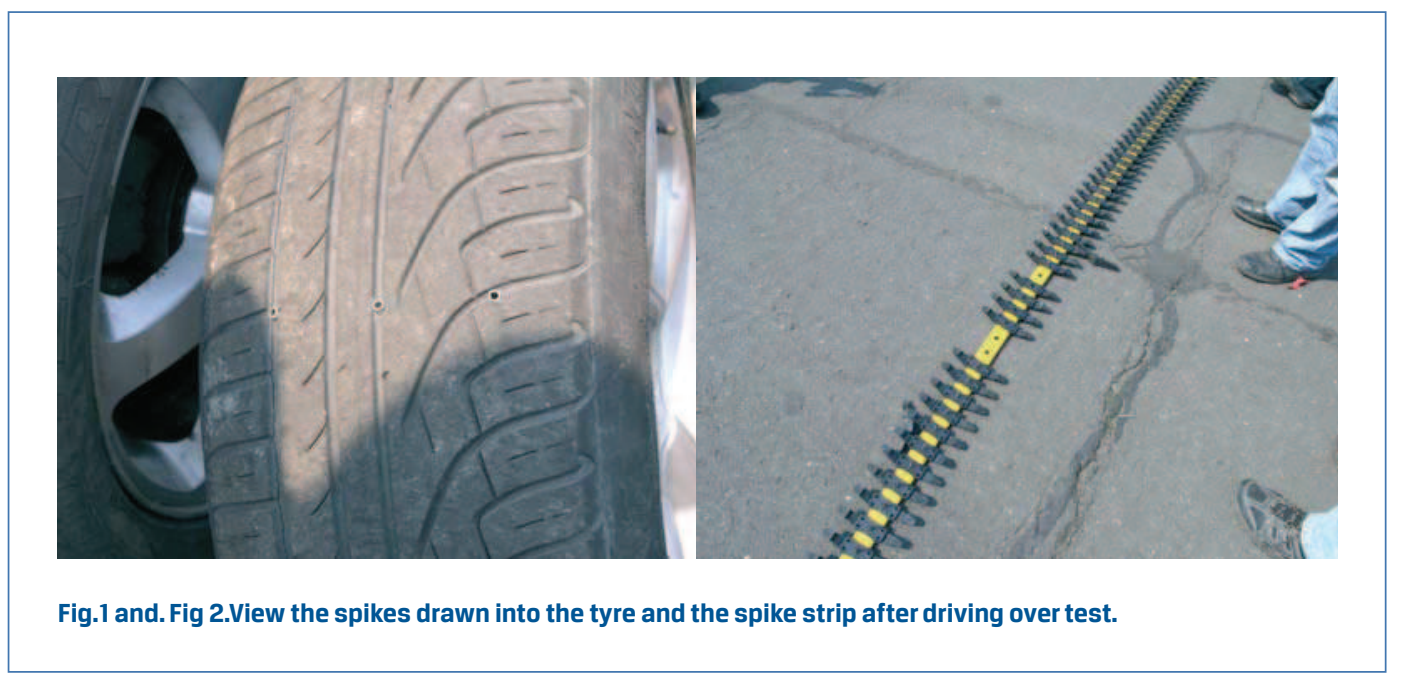

In most cases it is to estimate, that failure/pressure drop will undergo two wheels of front axle. However in dependence of front and rear wheel track and in some extent from driving speed, can come to failure of rear wheels, one or all.

Irrespectively to test configuration, breaking the vehicle equipped with ABS was stabile, driver didn't have to make great correction by steering wheel, and breaking distance wasn't considerably different from breaking distance of the vehicle with good tyres (Fig.3). In the case of failure the two wheels of steering axle, the vehicle was less sensitive to the steering wheel control, what was the smaller problem in the case of breaking along strait line, but caused great problem for driver, when breaking on curve or his efforts to continue driving.

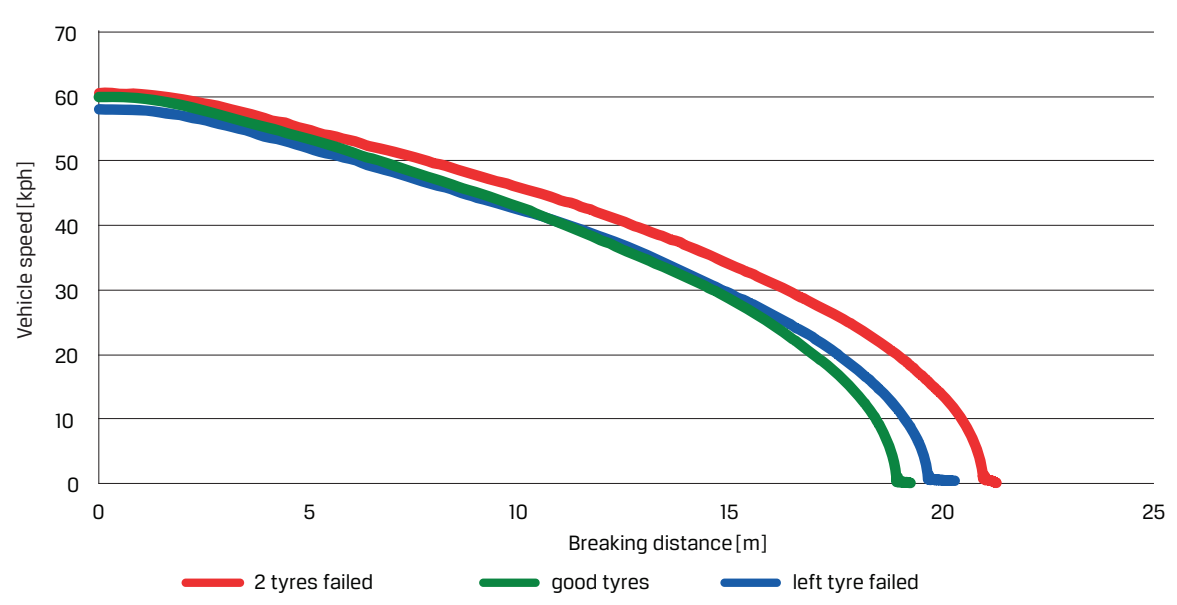

Fig. 3. Breaking distance diagrams for vehicles with good tyres and vehicle with failed front axle tyres. 
Driving over the spike strip have been done with speeds 60,100 and $140 \mathrm{kph}$. In the all tests the vehicle behave stabile in the moment of tyre puncture. The driver didn't feel in some exceptional way the moment of driving over the spike strip. Time, that elapsed to full tyre deflation was about $3 \mathrm{~s}$. During this time, when in tyres was full pressure, vehicle was fully driveable However after the pressure drop it comes to considerable loss of driveability. The vehicle become oversteer and practically it's control was limited to minimum (fig. 4 and 5).

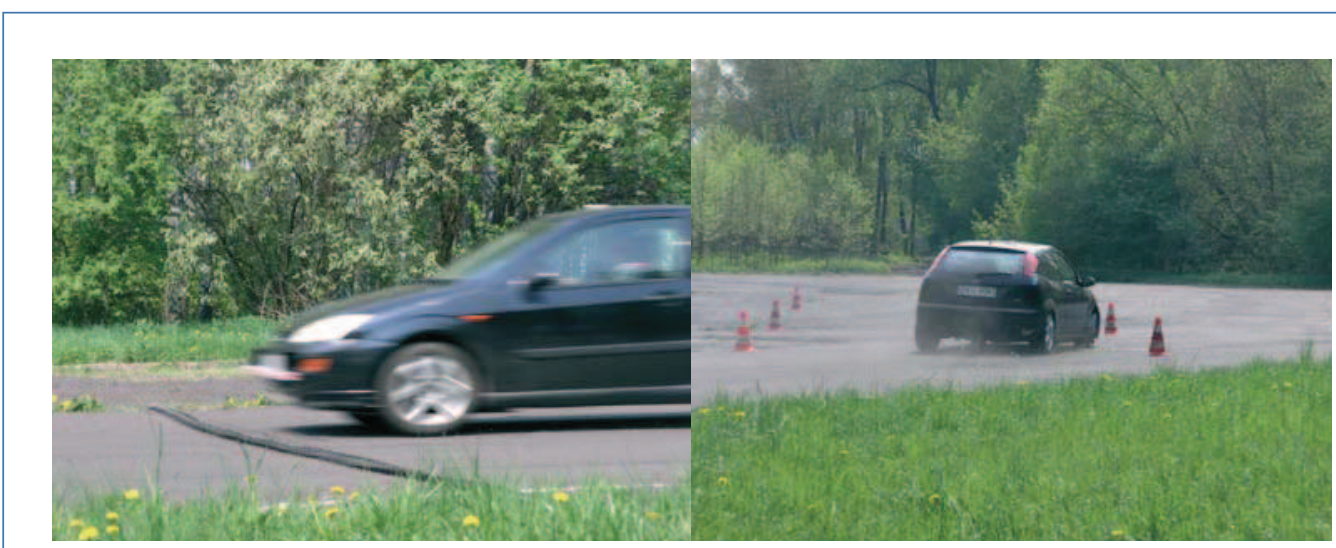

Fig. 4 and Fig. 5. The view of car driving thru spike strip and effort to driving trough the curve with punctured front wheel tyres (vehicle strongly oversteer).

Thus very danger is period after driving over the spike strip, when driver doesn't realize yet, that within a while the vehicle will be practically uncontrollable. During the first period, when it is still air in the tyres, he can be convinced, that the spike strip didn't make any effect. However after about 3 seconds, vehicle discontinue to be controllable. It is especially danger when after driving over the road spike strip the driver will intent to make a turn in built up area.

Thus in practice the road spike strip should be placed in order to after the driving over spike strip the road configuration should force driving the vehicle in straight line. The spike stripe shouldn't be placed just before the road curve. It creates the situation, where the driver won't be able to turn the vehicle, and falling out the road will create the hazard for other road participants.

\section{The use of Run On Flat tyres in police vehicles}

To test the resistance of wheel rim and tyre to the drive with lowered pressure, there had been done driving and breaking tests for standard tyres and tyres with reinforced shoulders Run On Flat type (denoted by Goodyear as RSC). Reinforcements in the sidewalls of this tyres enable, as to the producers, driving without pressure distance $80 \mathrm{~km}$ with speed $80 \mathrm{kph}$. Thicker shoulder should either protect the vehicle wheel rim and tyre against mechanical damage. 
Police vehicles very often drive as privileged vehicles, with high speed in the open road traffic. Therefore the parameters connected with stability and driveability of the vehicle should be very high. . The vehicles should be either accommodated to overcome typical urban and land obstacles, which they can encounter during pursuit on the hardened and gravel roads. Tyre of RSC type theoretically should be more resistive to mechanical damages, thus improving police vehicles mobility.

For each tyre type it have been done about 10 following each other breaking tests from the speeds 60 and $80 \mathrm{kph}$, and realized about $5 \mathrm{~km}$ drive with intensive acceleration and violent manoeuvres. The drives were done on the asphalt road, without significant damage and losses. In spite of low distance travelled, it come to total damage of standard tyre (fig6). The RSC type tyres didn't show any external signs of wear.

Though that the RSC type tire didn't show any signs of defects the external shoulder, the analyse of its structure after disassembling the tire from wheel rim showed it's quite substantial internal damage - substantial material loses (Fig. 7). After the test the tyre wasn't able to further use.

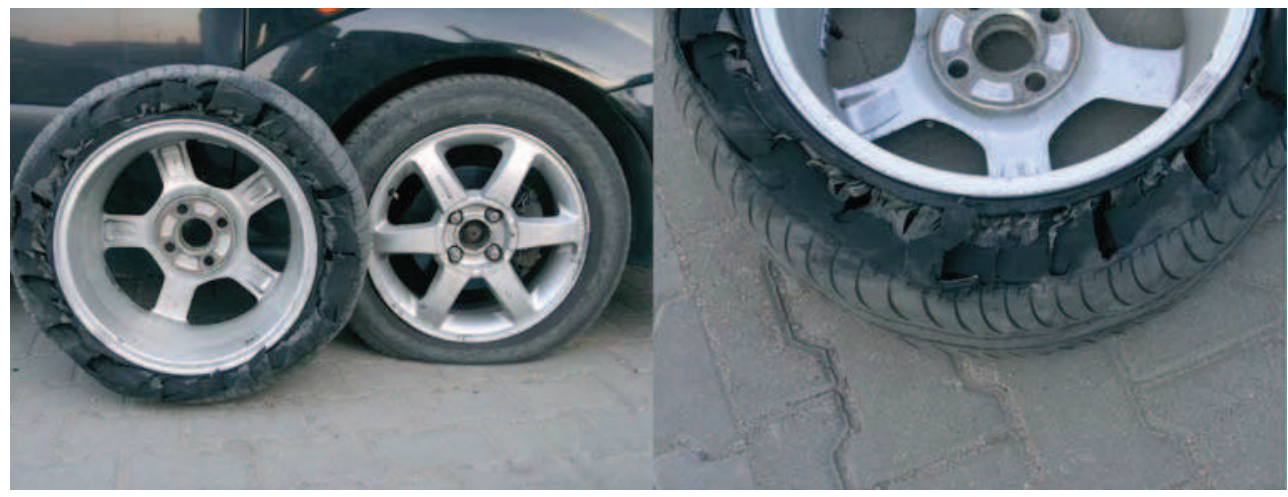

Fig 6. Comparison the visible external tyre wear of standard tyre(on left) with RSC type tyre.

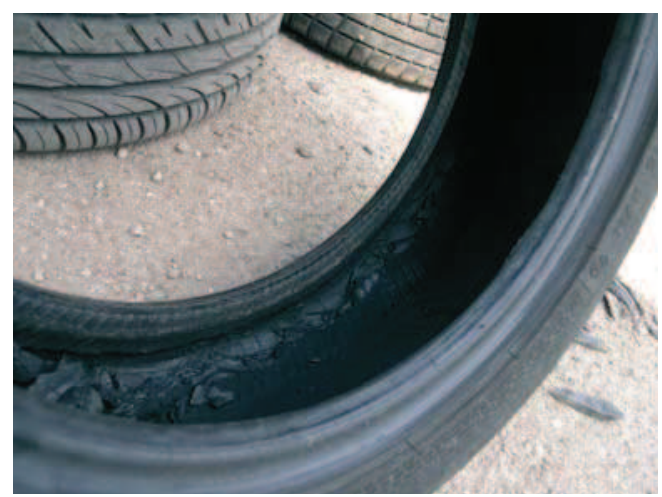

Fig.7. View the wear of internal side of RSC type tire. 
Additionally it has been observed very dangerous phenomena. This tyres keep the good driving stability only while driving in strait line. During dynamic drive on curve it comes to slide the tyre from the wheel rim (Fig,8) and dangerous situation of considerable worsening the adhesion of particular axle. Effect of sliding out the RSC type tire from wheel rim is exceptionally danger in the case of the vehicle rear axle. Vehicle presents then very high oversteering, difficult to master by the driver (Fig.9).

It is so dangerous phenomena, that in the case of standard tyre failure (Fig 10 and 11) it comes quickly to it completely slide out or damage and the same the necessity to stop the vehicle. Therefore the driver don't have physical possibility to continue the drive. In the case of RSC type tyre, driver convinced of possibility to continue the driving, can drive long distance with speed up to $100 \mathrm{kph}$ and in the moment of violent drive into road curve will be surprised by a vigorous vehicle reaction by the high speed.

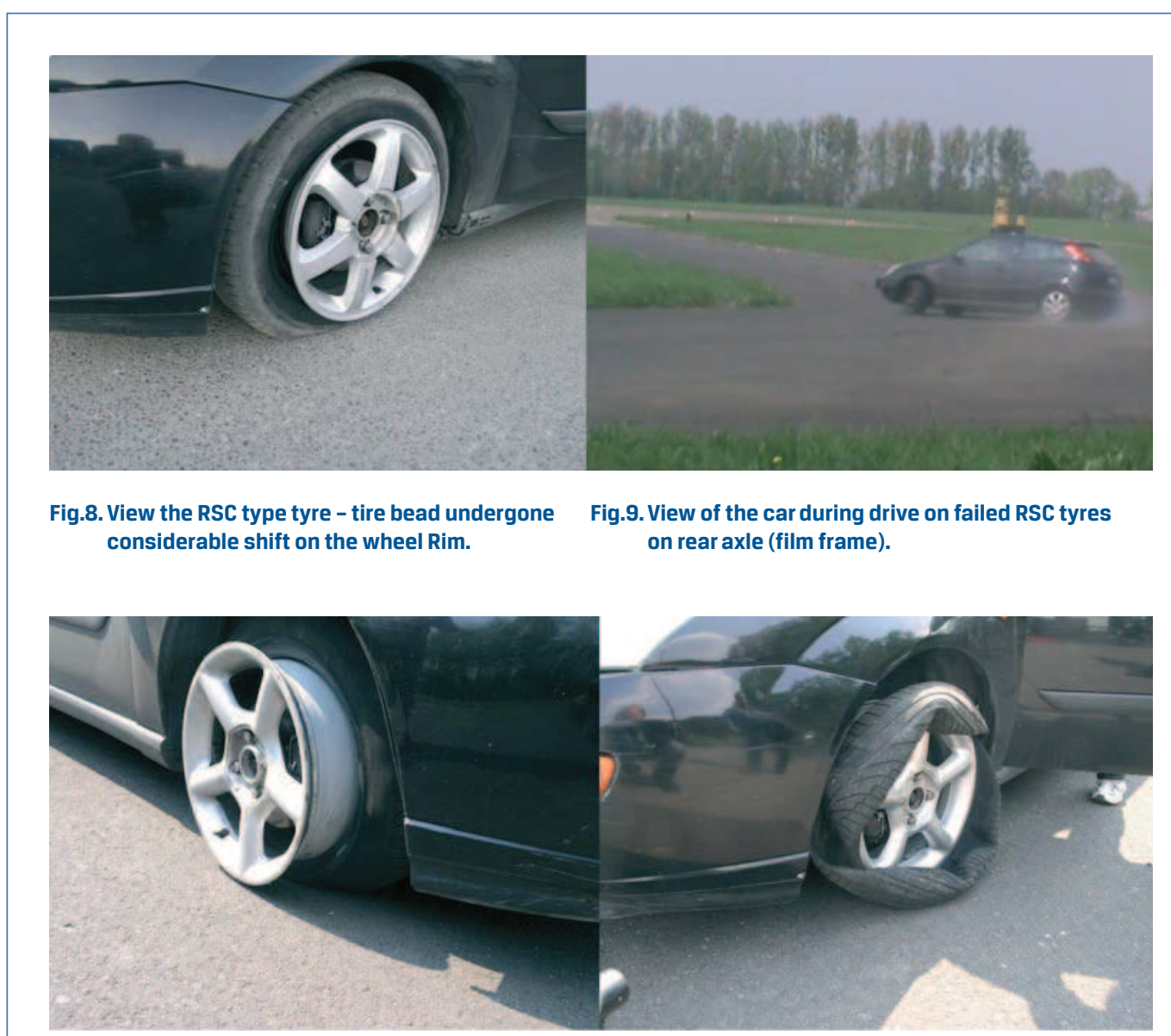

Fig. 10. and 11. View of the standard tyre damage after driving without pressure. 


\section{The wheel resistance to impact loads}

In the scope of the project it has been tested the resistance vehicle wheels to mechanical damage. Police vehicle wheels should be show very high resistance to typical town obstacle, as banquets or loses in the roadway. Tests of wheel rims and tyres resistance to impact loads have been done using special obstacle, designed in the scope of project (fig.12). The obstacle height has been determined as $10 \mathrm{~cm}$, the value similar to road banquets.

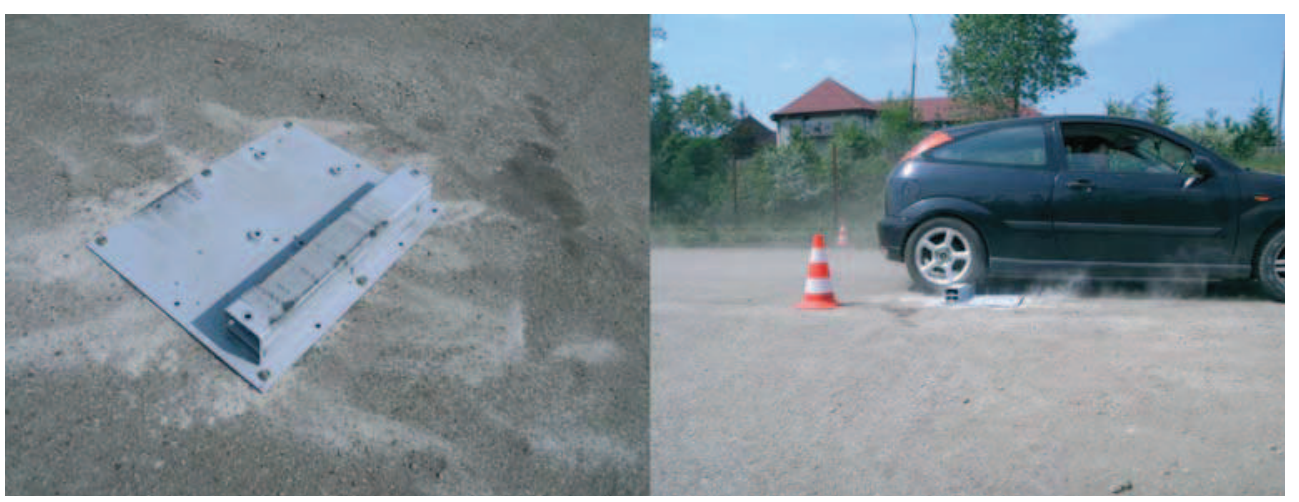

Fig.12. View of the obstacle for testing wheel rims and tyres to impact loads and vehicle under test.

The test consist of two driving over the obstacle with speed $50 \mathrm{kph}$ with the use of one piece of tested wheel. For the tests within the project it have been selected some combinations of the wheel rims and tyres, namely:

a) aluminium wheel rim and steel wheel rim with the same tyre type (Fig.13);

b) different types of aluminium wheel rims;

c) the same type of aluminium wheel rim with tyres with different tyre profile (Fig.14);

d) steel wheel rims with tyres with different tyre profile.

The detailed test results will be used for works upon requirements for chassis for police vehicles. However on the present stage it can be stated, that in the effects of failures analysis of described in the paper tyres of RSC type, they have good resistance to mechanical defects.

However it is to notice that the tests results very often were ambiguous. For instance it has been stated that high profile tyre considerably protects the wheel rim against the damages. But the tyre alone can be more sensitive to the cord cutting. In the case of tyres with low profile (profile $40-55$ ) it is the higher probability the damage of wheel rim. It however depends on the tyre design and its shoulder rigidity. Therefore during the tests similar damages have been observed for tyre 205/40R16 as for 205/55R16, besides the first tyre with lower profile characterized distinctly more rigid shoulder. 


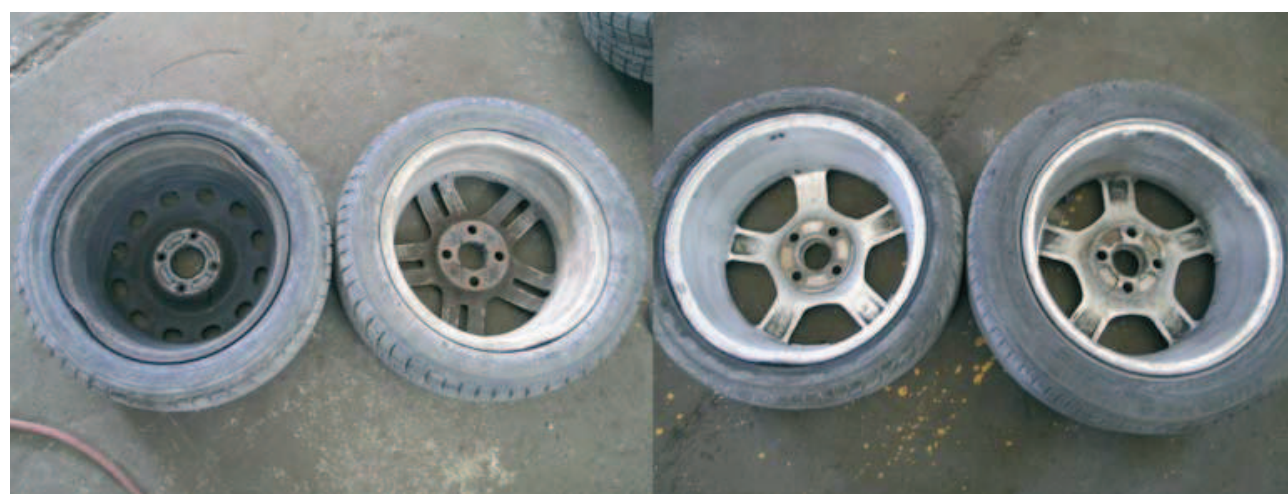

Fig.13. Comparison the defects of aluminium wheel rims with the same tyre types.

Fig. 14. Comparison defects of one type wheel rims by different tyre profile.

Within the project have been done another tests, for instance breaking efforts of police vehicle equipped with different type of friction linings Results of the tests will be published after finishing the project and elaboration final requirements according to the effectiveness of breaking systems.

\section{Statements}

Halting the vehicles by police using road spike strip is effective. After the drop down the pressure in tyres, vehicle becomes low driveable and further drive is very difficult. It is to remember, that road spike strip should be placed in a such way that the driver will have enough time to realize that vehicle's driveability worsens and that there is proper strait road segment to halt the vehicle. The RSC type tyres enable driving without pressure in tyres, practically it is possible only with low speed and on the strait road. In the case of acting onto tyres strong side forces, it comes to its slide from the wheel rim and abrupt falling down the driveability of the vehicle.

\section{References}

[1] STRY]EK P., MOTORYCZ G.: WITPIS reports, years 2010 - 2011. 


\title{
HAMOWANIE POJAZDÓW OSOBOWYCH PO PRZEBICIU OPONY POLICYJNA KOLCZATKA, W PRZYPADKU OPON STANDARTOWYCH I OPON TYPU RUN ON FLAT
}

\author{
PIOTR STRYJEK'', GRZEGORZ MOTRYCZ², JERZY GRZESIAK ${ }^{3}$ \\ Wojskowy Instytut Techniki Pancernej i Samochodowej \\ Przy współpracy: AMZ KUTNO www.amz.pl
}

\section{Streszczenie}

Operacja zatrzymania kierowcy niepodporządkowującego się poleceniom Policji, jest bardzo trudna i niebezpieczna. Zagrożenie może dotoczyć zarówno samego funkcjonariusza, osoby zatrzymywanej, jak i osób postronnych. W ramach badań wykonano serie kontrolowanych przejazdów po kolczatce policyjnej z różnymi prędkościami, zaczynając od typowych prędkości w ruchu miejskim, aż do osiągnięcia prędkości charakterystycznych dla jazdy po autostradzie. Sprawdzano nie tylko zachowanie się pojazdu podczas momentu przebicia opony, ale również kierowalność i stateczność pojazdu podczas jazdy z już uszkodzoną oponą. Wykonano także porównanie standardowych opon i opon typu Run On Flat, umożliwiających jazdę bez ciśnienia powietrza. Dla obu typów opon przeprowadzono sprawdzenie skuteczności hamowania i wykonano jazdy przebiegowe, aż do chwili całkowitego zniszczenia barku opony. Badania te miały na celu sprawdzenie przydatności opon typu Run On Flat, w pojazdach policyjnych. Prace były realizowane w ramach projektu badawczo-rozwojowego nr OR00000911, "Opracowanie wymagań technicznych i zakresu niezbędnego wyposażenia dla pojazdów policyjnych, na podstawie badań wzorcowych demonstratorów", prowadzonego przez WITPiS wraz z firmą AMZ Kutno.

Słowa kluczowe: pojazdy policyjne, hamowanie pojazdem z uszkodzonym ogumieniem, Run On Flat, kierowalność i stateczność

\footnotetext{
1 ul Okuniewska 1 05-070 Sulejówek Polska, tel.+48 22-6-811-044, e-mail: piotr@stryjek.eu, fax: +48 6-811-073

${ }^{2}$ ul Okuniewska 1 05-070 Sulejówek Polska, tel.+48 22-6-811-044, e-mail: grzegorz.motrycz@witpis.eu, fax: +48 6-811-073

${ }^{3}$ ul Okuniewska 1 05-070 Sulejówek Polska, tel.+48 22-6-811-044, fax: +48 6-811-073
} 


\begin{abstract}
1. Wstęp
Operacja zatrzymania kierowcy niepodporządkowującego się poleceniom Policji jest bardzo trudna i niebezpieczna. Zagrożenie może dotoczyć zarówno samego funkcjonariusza, osoby zatrzymywanej, jak i osób postronnych. Związane jest to nie tylko z samym momentem przebicia opon w pojeździe zatrzymywanym, co z kontynuowaniem jazdy po przebiciu opony. Pojazd bez powietrza w kołach jest bardzo trudny w kierowaniu, a jego stateczność jest bardzo ograniczona.
\end{abstract}

W ramach badań wykonano serie kontrolowanych przejazdów po kolczatce policyjnej z różnymi prędkościami. Sprawdzano nie tylko zachowanie się pojazdu podczas momentu przebicia opony, ale również zachowanie się pojazdu podczas jazdy z już uszkodzoną oponą. Wykonano również porównanie standardowych opon i opon typu Run On Flat (RSC), umożliwiających jazdę bez ciśnienia powietrza.

Prace były realizowane $w$ ramach projektu badawczo-rozwojowego nr OR00000911, „Opracowanie wymagań technicznych i zakresu niezbędnego wyposażenia dla pojazdów policyjnych, na podstawie badań wzorcowych demonstratorów", prowadzonego przez WITPiS wraz z firmą AMZ Kutno.

Pojazdy policyjne bardzo często poruszają się jako pojazdy uprzywilejowane, osiągając duże prędkości w otwartym ruchu drogowym. Dlatego parametry związane ze statecznością i kierowalnością pojazdu powinny być bardzo wysokie. Pojazdy powinny być także przystosowane do pokonywania typowych przeszkód urbanistycznych i terenowych, jakie mogą napotkać podczas pościgów na drogach utwardzonych i szutrowych. Opony RSC charakteryzują się wzmocnionymi ściankami bocznymi i konstrukcją opasania. Cechy te sprawiają, że opony tego typu mogłyby stanowić opcjonalne wyposażenie pojazdów policyjnych. Opona typu RSC teoretycznie powinna być bardziej odporna na uszkodzenia mechaniczne, przez co podnosić mobilność pojazdów policyjnych

\title{
2. Zatrzymywanie pojazdu z użyciem kolczatki policyjnej
}

Konstrukcja kolczatki policyjnej składa się z szeregu cienkich, ostro zakończonych rurek. Podczas przejeżdżania pojazdu po kolczatce, następuje wbicie się rurki w oponę i jej celowe wyrwanie z pasa kolczatki (rys 1 i 2). Ma to za zadanie przyspieszenie procesu spadku ciśnienia w oponie. W przypadku, gdyby kolczatka składała się z jednolitych, pełnych kolców, pozostających dodatkowo w pasie po przejechaniu pojazdu, miejsce przebicia opony mogłoby ulegać częściowemu samoczynnemu zasklepianiu, przez co efektywność spadku ciśnienia w oponie byłaby bardzo mała.

Po przebiciu opony badano drogę hamowania pojazdu sprawnego i z uszkodzonymi oponami. Wykonywano próbę hamowania ze sprawnymi oponami, jedną przebitą oponą i z przebitymi obiema oponami osi przedniej. Próby wykonywano dla prędkości 60 i $80 \mathrm{~km} / \mathrm{h}$. Należy w tym miejscu podkreślić, że istnieje pewna losowość, dotycząca ilości opon przebitych podczas przejazdu. W większości przypadków należy przyjąć, że 

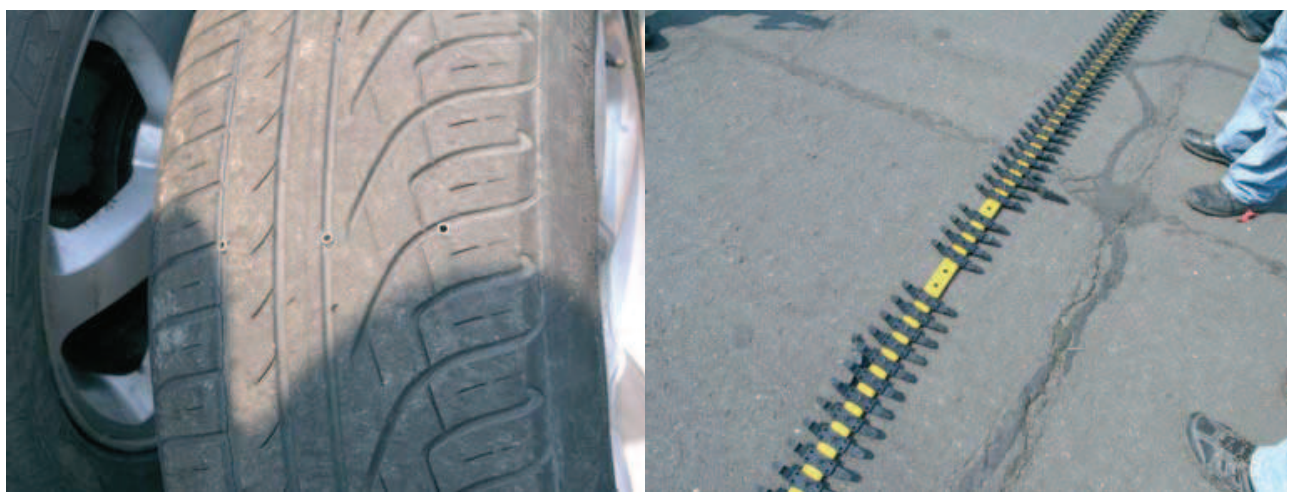

Rys. 1.i 2 Widok kolców wbitych w oponę oraz kolczatki po próbie przejazd.

uszkodzeniu/utracie ciśnienia będą podlegać dwa koła osi przedniej. Jednak w zależności od rozstawu kół przednich i tylnych pojazdu, a także w pewnym stopniu od prędkości przejazdu, może dojść do uszkodzenia także kół osi tylnej, jednego lub wszystkich.

Niezależnie od konfiguracji próby, badany pojazd wyposażony w układ ABS hamował stabilnie, kierowca nie musiał wykonywać dużych korekt kierownicą, a droga hamowania nie odbiegała znacząco od drogi hamowania pojazdu sprawnego (wykres $\mathrm{nr}$ 1). W przypadku uszkodzenia dwóch kół osi kierowanej, pojazd stawał się mało wrażliwy na reakcje kierownicą, co stanowiło mniejszy problem w przypadku hamowania prostoliniowego, jednak powodowało bardzo duży kłopot dla kierowcy, w przypadku hamowania w łuku lub próby dalszej jazdy.

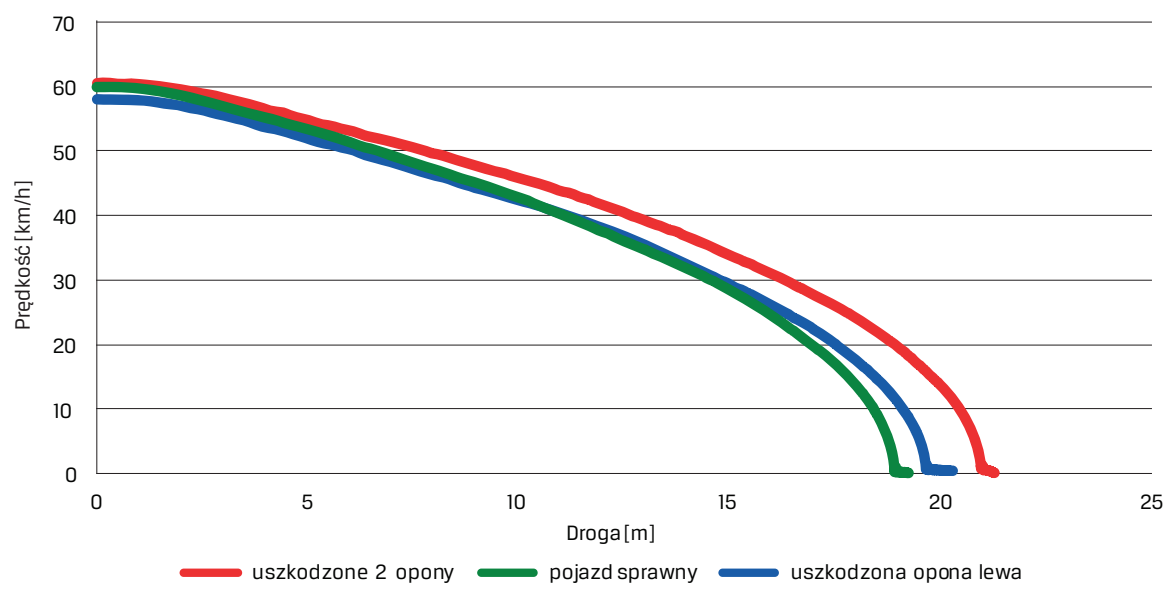

Wykres nr 1. Charakterystyki drogi hamowania dla pojazdu sprawnego i z uszkodzonymi kołami osi przedniej. 
Próby przejazdu przez kolczatkę wykonywano z prędkością 60, 100 i 140 km/h. Podczas wszystkich prób, pojazd zachowywał się stabilnie w momencie przebicia opon. Kierowca nie odczuwał w sposób szczególny momentu przejechania przez kolczatkę. Czas, po upływie którego dochodziło do pełnej utraty ciśnienia w oponie wynosił około 3 sekund. Przez ten czas, w momencie gdy w oponach było jeszcze ciśnienie, pojazd był w pełni kierowalny. Jednak po spadku ciśnienia dochodziło do znaczącego pogorszenia kierowalności. Pojazd stawał się silnie podsterowny i praktycznie kierowanie nim było ograniczone do minimum (rys 3 i 4).

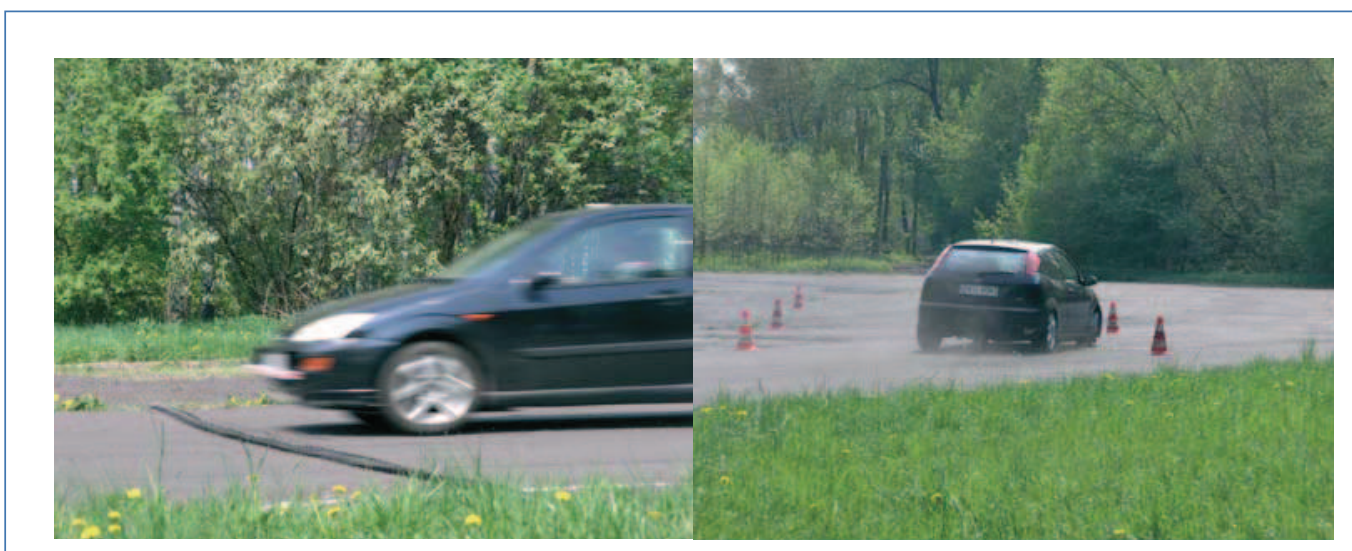

Rys. 3. i 4. Widok pojazdu przejeżdżającego przez kolczatkę i próba wejścia w łuk pojazdu z przebitymi oponami osi przedniej (pojazd silnie podsterowny).

Szczególnie niebezpieczny jest wiec okres po przejechaniu przez kolczatkę, w którym kierowca nie zdaje sobie jeszcze sprawy, że pojazd za chwilę stanie się praktycznie niesterowalny. Przez pierwszy okres, gdy w oponach jest jeszcze powietrze, może być on wręcz przekonany, że system kolczatki nie zadziałał. Jednak po okresie około 3 sekund, pojazd przestaje być sterowny. Jest to szczególnie niebezpieczne, gdy np. po przejechaniu przez zaporę drogową, kierujący będzie chciał wykonać skręt pojazdem w terenie zabudowanym.

Tak wiec blokada drogowa w praktyce powinna być ustawiona w taki sposób, aby po przejechaniu przez kolczatkę układ jezdni wymuszał dalsze poruszanie się pojazdu w linii prostej. Kolczatka nie może być ustawiona bezpośrednio np. przed łukiem drogi. Powoduje to sytuację, gdzie kierowca nie będzie w stanie skręcić pojazdem i wypadając z drogi będzie stanowił dodatkowe zagrożenie dla innych uczestników drogi.

\section{Wykorzystanie opon typu Run On Flat w pojazdach policyjnych}

W celu sprawdzenia odporności felgi i opony na jazdę przy obniżonym ciśnieniu, wykonano próby jazdy i hamowania dla opon standartowych i opon ze wzmocnionymi barkami 
typu Run-On-Flat (oznaczenie producenta Goodyear - RSC). Wzmocnienia w ściankach tych opon pozwalają według producentów na jazdę bez powietrza z prędkością do $80 \mathrm{~km} / \mathrm{h}$ przez $80 \mathrm{~km}$. Grubszy bark powinien także zabezpieczać oponę i felgę pojazdu przed uszkodzeniami mechanicznymi.

Dla każdego z typu opon wykonano około 10 następujących po sobie prób hamowania z prędkości 60 i $80 \mathrm{~km} / \mathrm{h}$ oraz wykonano przebieg około $5 \mathrm{~km}$ z intensywnym przyspieszaniem i gwałtownymi manewrami. Przejazdy wykonywane były po nawierzchni asfaltowej, bez znaczących uszkodzeń i ubytków. Mimo niewielkiego przebiegu bez powietrza, doszło do całkowitego uszkodzenia opony standartowej (rys 5). Opona typu RSC nie wykazywała z zewnątrz oznak zużycia.

Mimo, że opona typu RSC nie wykazywała oznak uszkodzeń zewnętrznego barku, to analiza jej struktury po zdjęciu opony z felgi wykazała dosyć znaczące jej uszkodzenia wewnętrzne - znaczące ubytki materiału (rys 6). Opona po próbie nie nadawała się praktycznie do dalszej eksploatacji.

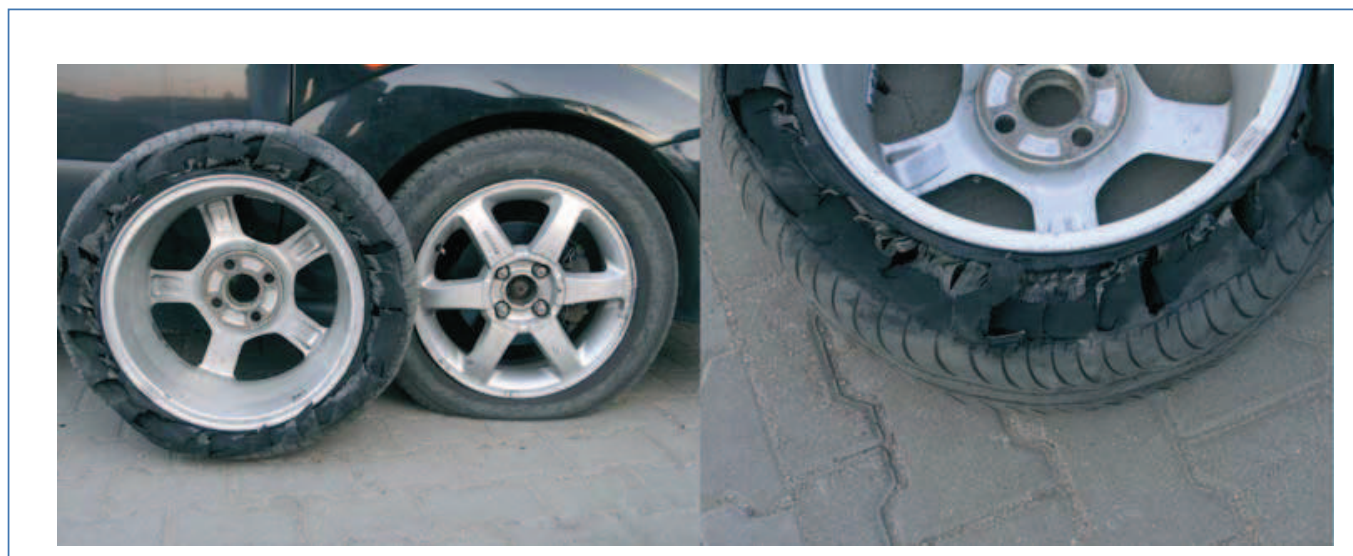

Rys. 5. Porównanie widocznego zużycia zewnętrznego opony standardowej (z lewej) z oponą typu RSC.

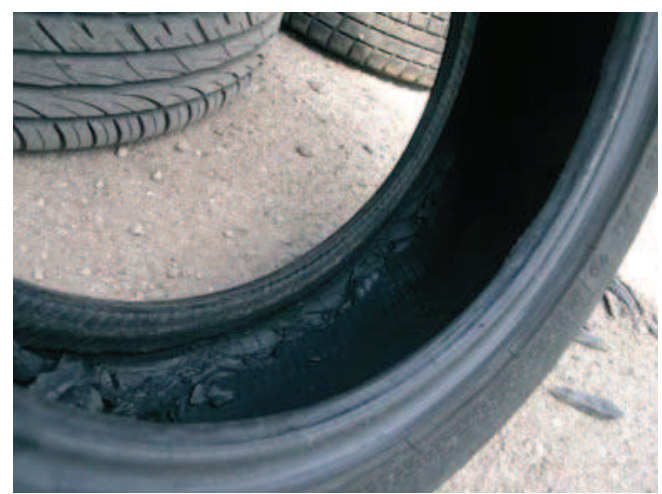

Rys. 6. Widok zużycia wewnętrznej strony opony typu RSC. 
Dodatkowo, zauważono bardzo niebezpieczne zjawisko. Opony te zachowują dobrą stateczność ruchu jedynie podczas jazdy na wprost. Podczas dynamicznej jazdy w zakręcie dochodzi do zsuwania się opony z obręczy (rys 7) i niebezpiecznej sytuacji znaczącego pogorszenia się przyczepności poszczególnych osi pojazdu. Efekt zsuwania się opony typu RSC z obręczy jest szczególnie niebezpieczny w przypadku osi tylnej pojazdu. Pojazd charakteryzuje się wtedy bardzo silna nadsterownością, trudną do opanowania przez kierowcę (rys 8).

Jest to o tyle niebezpieczne zjawisko, że w przypadku uszkodzenia standardowej opony (rys 9 i 10) dochodzi bardzo szybko do jej całkowitego zsunięcia się lub zniszczenia i tym samym konieczności zatrzymania pojazdu. Kierowca nie ma więc możliwości fizycznej kontynuowania jazdy. W przypadku opony typu RSC, kierowca przekonany o możliwości kontynuowania jazdy, może pokonać długi dystans z prędkościami dochodzącymi do $100 \mathrm{~km} / \mathrm{h}$ i w momencie gwaltownego wejścia w tuk drogi, zostanie zaskoczony gwaltowna reakcją pojazdu przy dużej prędkości.

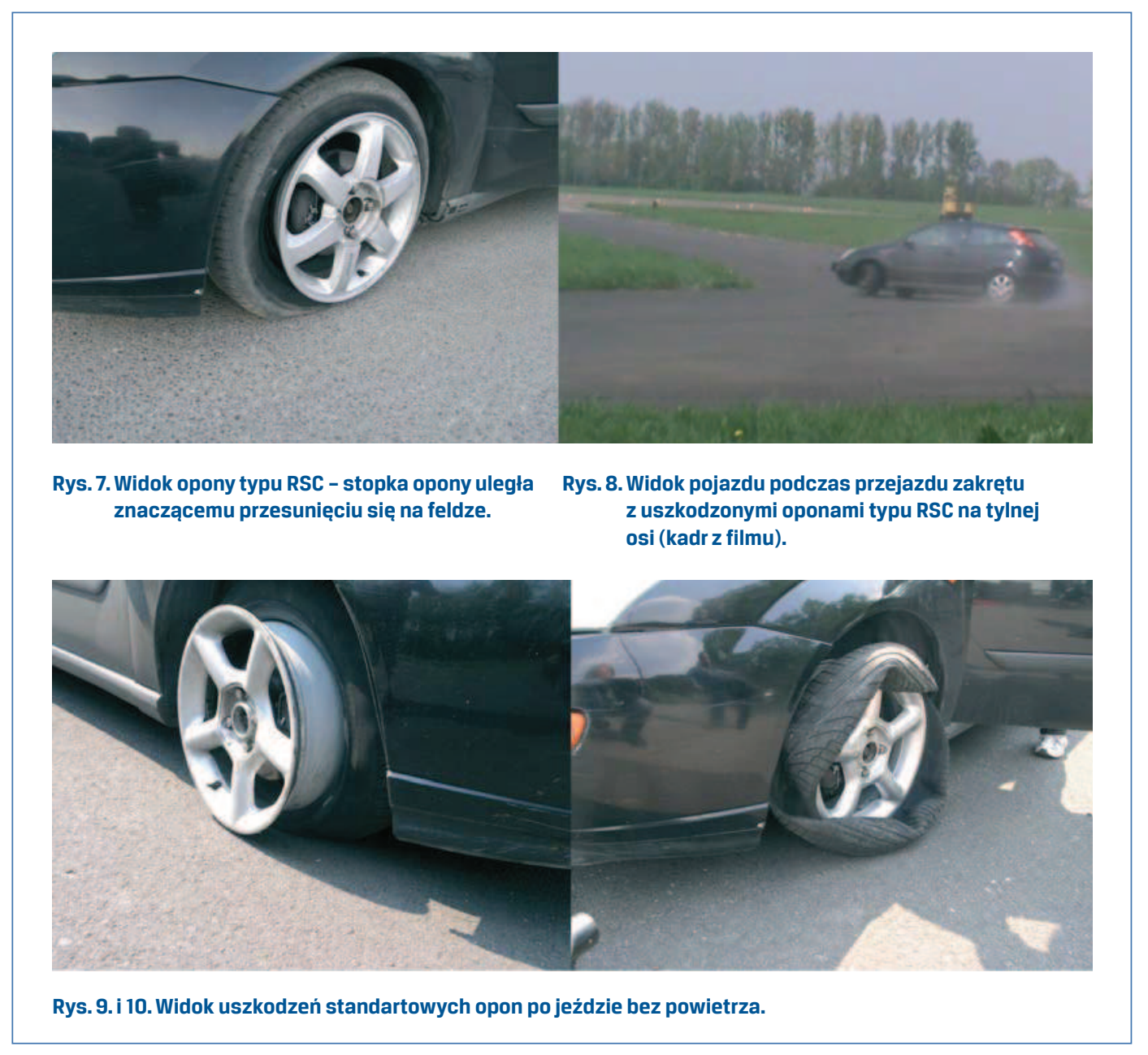




\section{Odporność kół na obciążenia udarowe}

W ramach projektu badano również odporność kół pojazdu na uszkodzenia mechaniczne. Koła pojazdu policyjnego powinny charakteryzować się bardzo dużą odpornością na typowe przeszkody miejskie, typu krawężniki lub ubytki w jezdniach. Badania odporności felg i opon na obciążenia udarowe wykonano z użyciem specjalnej przeszkody zaprojektowanej w ramach projektu (rys 11). Wysokość przeszkody ustalono na $10 \mathrm{~cm}$, jako wartość zbliżoną do wysokości krawężnika drogowego.

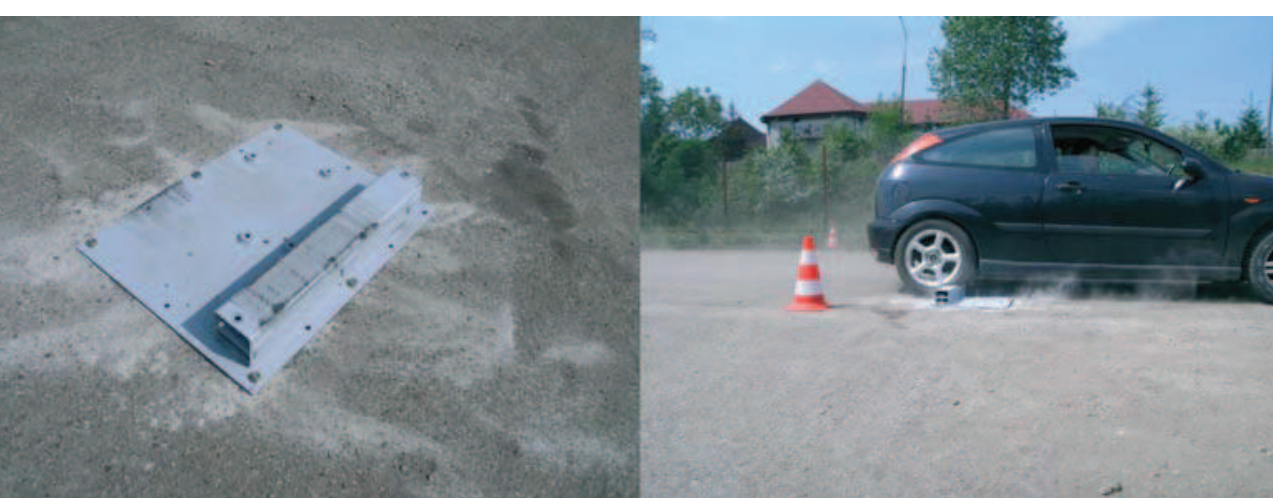

Rys. 11. Widok przeszkody do sprawdzania odporności felg i opon na obciążenia udarowe oraz pojazdu podczas próby.

Próba polegała na dwukrotnym przejeżdżaniu przeszkody z prędkością $50 \mathrm{~km} / \mathrm{h}$, z użyciem jednego egzemplarza badanego koła. Do próby wykonywanych w projekcie wytypowano kilka kombinacji opon i felg, m.in.:

a) felga stalowa i aluminiowa z tym samym modelem opony (rys 12);

b) różnego typu felgi aluminiowe;

c) ten sam model felgi aluminiowej z oponami o różnym profilu opony (rys 13);

d) felgi stalowe z oponami o różnym profilu opony.

Szczegółowe wyniki badań zostaną wykorzystane podczas opracowywania wymagań dla podwozi pojazdów policyjnych. Jednak już na obecnym etapie można stwierdzić, że w wyniku analizy uszkodzeń opisywanych w niniejszym artykule opon typu RSC, charakteryzują się one rzeczywiście dobrą odpornością na uszkodzenia mechaniczne.

Należy jednak podkreślić, że podczas wszystkich prób wyniki były często niejednoznaczne. Na przykład stwierdzono, że wysoki profil opony w dużym stopniu zabezpiecza felge przed uszkodzeniami. Sama opona może jednak być podatna na przecięcie kordu. W przypadku opon o niski profilu (profil 40 - 55), felga jest narażona na większe prawdopodobieństwo uszkodzenia. Jest to jednak zależne od konstrukcji samej opony i sztywności jej barku. Dlatego podczas prób, podobne uszkodzenia zauważono np. dla opony 205/40R16 jak i 205/55R16, przy czym pierwsza opona o niższym profilu charakteryzowała się wyraźnie sztywniejszym barkiem. 


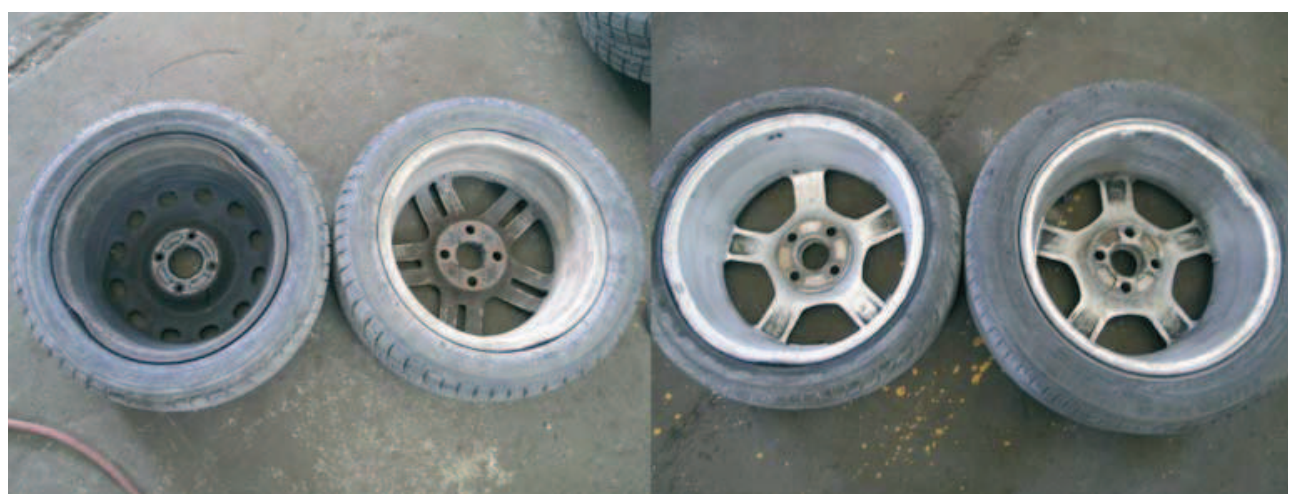

Rys. 12. Porównanie uszkodzeń felgi stalowej i aluminiowej przy tym samym typie opony.

Rys. 13. Porównanie uszkodzeń jednego typu felg aluminiowych przy różnym profilu opony.

Podczas badań w projekcie prowadzono także inne sprawdzenia, m.in. skuteczności układu hamulcowego pojazdu policyjnego wyposażonego w różnego typu okładziny cierne. Wyniki z tych badań zostaną opublikowane po zakończeniu projektu i opracowaniu ostatecznych wymagań odnośnie skuteczności układów hamulcowych.

\section{Podsumowanie}

Zatrzymywanie pojazdów przez Policję z użyciem kolczatki jest skutecznym sposobem. Pojazd po utracie ciśnienia w kołach staje się mało sterowny i dalsza jazda staje się bardzo trudna. Należy jednak pamiętać, aby zapora drogowa była ustawiana w taki sposób, aby kierowca miał czas na po pierwsze uświadomienie sobie, że kierowalność pojazdu uległa pogorszeniu i po drugie miał odpowiednio długi odcinek prostej drogi, do zatrzymania pojazdu.

Opony typu RSC umożliwiają jazdę wprawdzie bez powietrza, jednak dotyczy to praktycznie jedynie jazdy z mniejszymi prędkościami po prostych odcinkach dróg. W przypadku długotrwałego i silnego poddawaniu opon działaniom sił bocznych, dochodzi do ich zsuwania się z obręczy i nagłego pogorszenia się kierowalności pojazdu.

\section{Bibliografia}

[1] STRYJEK, P., MOTYCZ, G.: Sprawozdania WITPiS z lat 2010-2011, niepublikowane. 